\title{
Effects of ethanol extract of curry leaves (Murraya koenigii) on HER2 and caspase- 3 expression in rat model mammary carcinoma
}

\author{
Siti Aisyah ${ }^{1,2}$ (i), Ekowati Handharyani3 ${ }^{3}$, Nurliani Bermawie ${ }^{4}$ (i) and Agus Setiyono ${ }^{3}$ (D)
}

1. Department of Clinic Reproduction and Pathology, Animal Biomedical Sciences Study Program, IPB University, Bogor, Indonesia; 2. Laboratory of Pathology, Faculty of Veterinary Medicine, Syiah Kuala University, Banda Aceh, Indonesia;

3. Department of Clinic Reproduction and Pathology, Division of Pathology, Faculty of Veterinary Medicine, IPB University, Bogor, Indonesia; 4. Department of Plant Genetic and Breeding, Indonesian Spices and Medicinal Crops Research Institute, Indonesian Agency for Agricultural Research and Development, Bogor, Indonesia.

Corresponding author: Agus Setiyono, e-mail: agusse@apps.ipb.ac.id

Co-authors: SA: drh.sitiaisyah.vet@gmail.com, EH: ekowatieko@apps.ipb.ac.id, NB: nurliani.bermawie@gmail.com Received: 20-12-2020, Accepted: 15-06-2021, Published online: 03-08-2021

doi: www.doi.org/10.14202/vetworld.2021.1988-1994 How to cite this article: Aisyah S, Handharyani E, Bermawie N, Setiyono A (2021) Effects of ethanol extract of curry leaves (Murraya koenigii) on HER2 and caspase-3 expression in rat model mammary carcinoma, Veterinary World, 14(8): 1988-1994.

\begin{abstract}
Background and Aim: Human epidermal growth factor receptor 2 (HER2/erbB2/neu) is a prognostic factor and biomarker for detecting mammary tumor malignancy. Leaves of curry (Murraya koenigii) contain alkaloid, flavonoid, and phenolic compounds that can be cytotoxic to tumor cells. Caspase-3 is an indicator of apoptosis in tumor cells. This study aimed to evaluate the effect of curry leaf extract on the expression of HER2 and caspase-3 in mammary tumor through immunohistochemical analyses.
\end{abstract}

Materials and Methods: Thirty five Sprague-Dawley rats were divided into seven groups: negative control of tumor (P1), positive control of tumor (P2), tumor therapy with methotrexate (P3), and curry leaf extract doses of 300 and $400 \mathrm{mg} /$ $\mathrm{kg}$ body weight/BW after tumor formation (P4, P5), and before tumor formation (P6, P7). Thirty rats of six groups were injected subcutaneously into the mammary glands with 7,12-dimethylbenz( $\alpha$-anthracene DMBA) twice within 2 weeks for mammary tumor formation. At the end of the treatments, the rats were euthanized, and their mammary glands were analyzed histopathologically and immunohistochemically using HER2 and caspase-3 antibodies.

Results: Regarding the expression of HER2 detected in the epithelial cell membrane of the mammary gland, P2, P3, P4, and P5 revealed positive expression, P6 and P7 showed equivocal expression, while P1 showed negative expression. Regarding caspase-3 expression in the cytoplasm of epithelial cells, it was low in P1, moderate in P2, P5, P6, and P7, and high in P3 and P4. These findings suggest that DMBA injection produced mammary tumors with HER2 as a biomarker of mammary tumor, and high caspase- 3 expression in P4 was the effect of curry leaves extract.

Conclusion: The extract of curry leaves at a dose of $300 \mathrm{mg} / \mathrm{kg} \mathrm{BW}$ with preventive and curative effects can potentially be used as an anti-tumor agent, which effectively induces the apoptosis of tumor cells.

Keywords: 7,12-dimethylbenz $(\alpha)$-anthracene, anti-tumor drug, apoptosis, herbal plant, human epidermal growth factor receptor 2, Murraya koenigii.

\section{Introduction}

Breast cancer remains the most prevalent cancer type in Indonesia, accounting for $16.7 \%$ of total tumors and having a mortality rate of $17 \%$ [1]. One approach to lowering the mortality due to mammary tumors is the early detection of mammary tumor malignancy. However, molecular analysis of tumor tissue only by pathological examination is inadequate for this purpose. An immunohistochemical examination is required to determine the developmental stage and receptor status, as well as to evaluate the efficacy of a given treatment [2]. Treatment strategies in malignant tumors were evaluated based on the correlation of clinical results

Copyright: Aisyah, et al. Open Access. This article is distributed under the terms of the Creative Commons Attribution 4.0 International License (http://creativecommons.org/licenses/by/4.0/), which permits unrestricted use, distribution, and reproduction in any medium, provided you give appropriate credit to the original author(s) and the source, provide a link to the Creative Commons license, and indicate if changes were made. The Creative Commons Public Domain Dedication waiver (http://creativecommons.org/ publicdomain/zero/1.0/) applies to the data made available in this article, unless otherwise stated. with diagnostic pathology [3]. Several biomarkers of breast tumors with prognostic or predictive value have been established, including estrogen receptor, progesterone receptor, and human epidermal growth factor receptor 2 (HER2) [4,5]. HER2 receptor can be used as an indicator for determining the malignancy of mammary tumors and suitable therapy. HER2/erbB2/ neu is a transmembrane protein receptor in the epidermal growth factor receptor group. HER2 has tyrosine kinase activity, in which receptor dimerization is produced during autophosphorylation of tyrosine residues within the cytoplasm domain receptor and initiates various signaling pathways that cause cell proliferation and tumorigenesis [5-7]. The overexpression of HER2 was found in $20-30 \%$ of mammary tumor cases. It is related to disease aggressiveness, high disease recurrence, and increased mortality [8-10].

Preventing tumors from developing to a later stage or lowering tumor malignancy can be achieved by evaluating the effectiveness of a given therapy. Evaluation of the effectiveness of therapy can be done 
by examining apoptosis. Apoptosis is a programmed cell death. Disturbed apoptosis is one of the characteristics of tumor development. Caspase-3 is the main initiator of the apoptotic cascade in tumor cells and is an important biomarker of apoptosis. The development of mammary tumors is closely related to the expression of caspase-3. Caspase-3 is part of the cysteine-aspartate protease acid (caspase) family, which plays a role in the apoptotic signaling pathway and regulates apoptosis [11]. The inhibition of apoptosis in tumor cells can increase bad prognosis. Various researchers have used apoptosis as the main target in the search for anti-tumor drugs [12-14]. Secondary metabolites in plants have high potential as anti-tumor drugs because it can cause cytotoxic and apoptosis in tumor cells, so that growth can be inhibited. Secondary metabolites with anti-tumor activity include alkaloids, flavonoids, and terpenoids [15].

One of the herbal plants containing these secondary metabolites is curry (Murraya koenigii), specifically, its leaves. In various studies, curry leaves have been proven to have anti-tumor effects both in vitro [16-19] and in vivo [20-22]. Studies indicated that curry leaves' alkaloid compounds could induce apoptosis in the mammary cancer cells MCF7, HeLa, P388, and HL-60 [23,24], as well as colon cancer cells HT-29 [25]. It was also described that flavonoid and phenolic compounds of curry leaves can be effective at preventing colon cancer in vitro [26].

However, in vivo research on curry leaves is still limited. This study was established to evaluate the effect of ethanol extract of curry leaves on the expression of HER2 and caspase-3 in mammary gland tumors in Sprague-Dawley (SD) rats through immunohistochemical analyses. HER2 expression was analyzed to reflect mammary tumor malignancy after the administration of 7,12-dimethylbenz $(\alpha)$-anthracene (DMBA), whereas the expression of caspase-3 was analyzed to show apoptosis of mammary tumor cells.

\section{Materials and Methods \\ Ethical approval}

The Ethical Committee has approved this research of Faculty of Veterinary Medicine, IPB University, Bogor, under certificate No. 094/KEH/ SKE/VIII/2018.

\section{Study period and location}

The study was conducted from August 2018 to August 2019 at the Laboratory Animal Management Unit and Laboratory of Pathology, Faculty of Veterinary Medicine, IPB University, Bogor, Indonesia.

\section{Curry leaf preparation}

A certified botanist performed taxonomic determination at the Herbarium Bogoriense LIPI Bogor. Curry leaves were obtained from around the Faculty of Veterinary Medicine, IPB University, Bogor. The leaves were aromatic, bright green, and shiny. The leaves were dried, ground, and sieved through a mesh 60 sieve. The dried leaves were then extracted with $70 \%$ ethanol using a maceration method. Curry leaf extract was then concentrated by a rotary evaporator at $40^{\circ} \mathrm{C}$ and $50 \mathrm{rpm}$ until a thick extract was obtained (Pharmacy Laboratory, Faculty of Veterinary Medicine, IPB University).

\section{Experimental design}

Female SD rats aged 3-4 months were obtained from the laboratory animal unit (UPHL), Faculty of Veterinary Medicine, IPB University. The rats were maintained in a well-ventilated room with a 12-h light/dark cycle and feed and water were supplied $a d$ libitum. Mammary tumor was induced using (DMBA; Sigma) at $20 \mathrm{mg} / \mathrm{kg}$ body weight(BW) dissolved in $1 \mathrm{ml}$ of olive oil injected subcutaneously into rat mammary glands twice with an interval of 7 days. Thirtyfive female SD rats were divided into seven groups (each group consisting of five rats). P1 was the normal group, which was only given a placebo $(2 \mathrm{ml}$ of distilled water for each experimental animal). P2 to P7 were the tumor treatment groups, treated with DMBA. P2 was the tumor control group, given distilled water. P3 was the control medicine group, given methotrexate (MTX) at $0.125 \mathrm{mg} / \mathrm{kg} \mathrm{BW}$ after tumor formation. The curative groups (P4 and P5) were given curry leaf ethanol extract (CLEE) at 300 or $400 \mathrm{mg} / \mathrm{kg} \mathrm{BW}$ after the tumor formed, while the preventive groups (P6 and P7) were given CLEE at 300 and $400 \mathrm{mg} / \mathrm{kg} \mathrm{BW}$ along with DMBA injection before the tumor formed. The extract and MTX were given to the rats orally for 30 days. Tumor palpation of the mammary gland was conducted after the last DMBA injection.

\section{Immunohistochemical staining and histopathologi- cal examination}

At the end of the treatment, all rats were euthanized and the mammary tumors were fixed in $10 \%$ neutral buffered formalin. Paraffin blocks were made and cut into $5 \mu \mathrm{m}$ slices for each rat. Three consecutive slices were stained immunohistochemically. Slides were incubated in antigen retrieved ( $\mathrm{pH} 6.0$ ), for $15 \mathrm{~min}$ at $95^{\circ} \mathrm{C}$, cooled at $27^{\circ} \mathrm{C}$ (room temperature/ RT) (for caspase-3 antibody), followed by washing with PBS. Slides were then incubated with endogenous activity blocking $\mathrm{H}_{2} \mathrm{O}_{2} 3 \%$ (Biocare Medical, California, USA) (HER2 and caspase-3 antibody) for 30 min at RT. Next, slides were incubated with primary antibody against HER2 (1:100; mouse monoclonal [3B5] antibody to ErbB2, ab16901; Abcam, Cambridge, UK) and caspase-3 (1:250; rabbit polyclonal antibody to caspase-3, ab4051; Abcam) at $4{ }^{\circ} \mathrm{C}$ overnight. Slides were incubated with a secondary antibody (Trekkit Universal Link; Biocare Medical) for $30 \mathrm{~min}$ at RT and were then incubated with Trek Avidin-HRP Label (Biocare Medical) for $30 \mathrm{~min}$ at RT. Following rinsing with PBS, visualization was performed using the peroxidase substrate 3,3-diaminobenzidine (Biocare Medical) as the chromogen. Then, counterstaining with hematoxylin was carried 
out, followed by mounting. Apart from the palpation method, the presence of a tumor mass was also confirmed through hematoxylin-eosin and Masson's trichrome staining.

\section{Statistical analysis}

Data were analyzed semi-quantitatively based on the immune reaction using a light microscope. A score was assigned based on the average value of each treatment group. Observations on each slide were carried out based on ten fields of view at $20 \times$ magnification. HER2 expression was observed based on the staining intensity of the epithelial cell membrane in mammary glands with the following categories: HER2negative (-): cell membrane unstained or $\leq 10 \%$ incompletely stained tumor cell membrane, $(+):>10 \%$ tumor cell membrane incompletely stained, HER2equivocal $(++)$ : $>10 \%$ tumor cell membrane incompletely stained or weakly stained or $\leq 10 \%$ tumor cell membrane completely stained, and HER2-positive $(+++):>10 \%$ tumor cell membrane homogeneously stained [27]. Caspase-3 expression was observed based on staining intensity in mammary gland cell cytoplasm with the categories of low $(+)$, moderate $(++)$, and high $(+++)$.

\section{Results}

The results showed that breast tumor nodule formation could be detected by palpation in about $40-60 \%$ of the rats at 14 days after DMBA injection, while on the $21^{\text {st }}$ day, tumor nodules had formed in $100 \%$ of the injected rats. Figure- 1 shows the clinical features of the mammary glands on the $7^{\text {th }}$ day after the initial injection of DMBA. The mammary glands became inflamed, red, and had nodules with a soft consistency. Palpation of the mammary gland tumor nodules as performed on day 14 showed a spongy to hard consistency. In terms of the consistency of the tumors, they were single solid masses adhering to the skin and abdominal wall. The shapes of the tumors varied, such as being round, oval, and flattened. Some of the tumor nodules were visible on the surface of the skin, while others were not. Tumors that were not visible on the surface of the skin indicated tumor progression into the abdomen.

The results of HER2 and caspase- 3 expression in $\mathrm{SD}$ rats as revealed by IHC are shown in Table-1. HER2 protein was homogeneously expressed on the epithelial cell membrane of mammary glands. Evaluation of HER 2 protein was indicated by the stained cell membrane. Membrane cells were light brown stained incompletely (++/equivocal) and light/dark brown stained completely (+++/positive) (Figure-2). HER2 overexpression in rat mammary tumors was found by epithelial cell proliferation in mammary gland duct and epithelial cells located between polymorphonuclear (PMN) cells.

The HER2 overexpression indicated the malignancy of mammary gland tumors. Based on HER2 overexpression, P2, P3, P4, and P5 groups were diagnosed as having malignant tumors due to mammary carcinogenesis induced by the two subcutaneous injections of DMBA. DMBA proved to be highly carcinogenic to the rats and induced malignancy in the P2, P3, P4, and P5 groups. Meanwhile, in the P6 and

Table-1: Expression of HER2 and caspase-3 in SpragueDawley rats.

\begin{tabular}{llll}
\hline Groups & Treatment & $\begin{array}{l}\text { HER2 } \\
\text { expression }\end{array}$ & $\begin{array}{l}\text { Caspase-3 } \\
\text { expression }\end{array}$ \\
\hline P1 & NC & - & + \\
P2 & TC & +++ & ++ \\
P3 & TT+MTX & +++ & +++ \\
P4 & TTC+CLEE $300 \mathrm{mg} /$ & +++ & +++ \\
& kg BW & & ++ \\
P5 & TTC+CLEE $400 \mathrm{mg} /$ & +++ & ++ \\
& kg BW & & ++ \\
P6 & TTP+CLEE $300 \mathrm{mg} /$ & ++ & ++ \\
& kg BW & & + \\
P7 & TTP+CLEE $400 \mathrm{mg} /$ & ++ & + \\
& $\mathrm{kg} \mathrm{BW}$ & & \\
\hline
\end{tabular}

HER2 = Human epidermal growth factor receptor 2, $\mathrm{NC}=$ Normal control, $\mathrm{TC}=$ Tumor control, $\mathrm{TT}=$ Tumor treatment, $\mathrm{MTX}=$ Methotrexate, $\mathrm{CLEE}=$ Curry leaves ethanol extract, $\mathrm{C}=$ Curative, $\mathrm{P}=$ Preventive

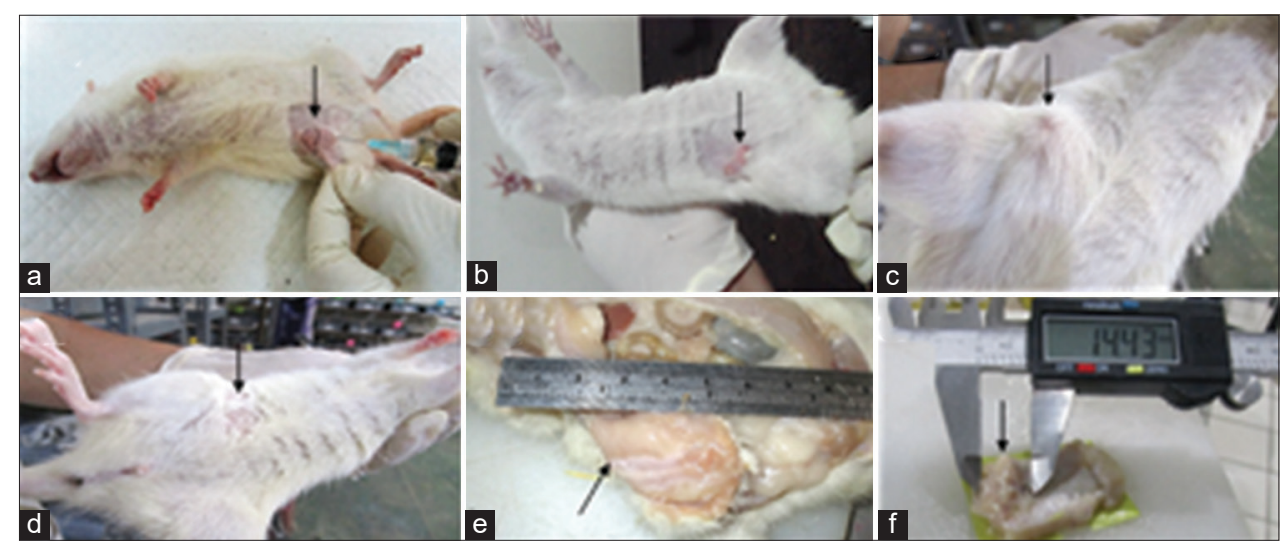

Figure-1: Mammary tumors in Sprague-Dawley rats. (a) Injection of 7,12-dimethylbenz( $\alpha$ )-anthracene (DMBA) into the subcutaneous of the right mammary gland, (b) 7 days after the initial injection of DMBA, (c) Tumor nodules were visible on the skin surface, (d) Tumor nodules were not visible on the surface of the skin, (e and f) The tumor adhered to the skin and abdominal wall. 


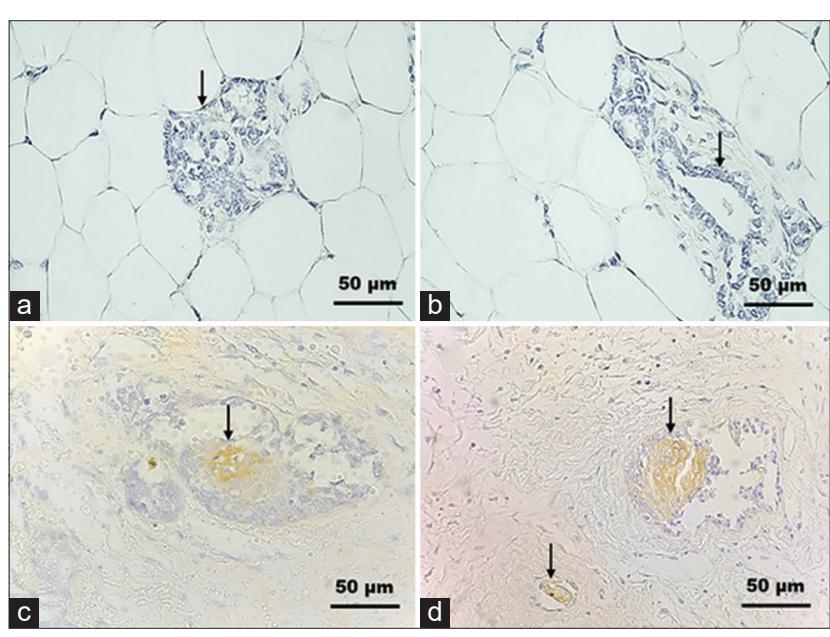

Figure-2: Expression of human epidermal growth factor receptor 2 (HER) on the membrane of the epithelial cells of the mammary gland (arrow). ( $a$ and b) The mammary gland a negative control in the P1 group. (c) Equivocal expression $(++)$ in the P6 group. (d) Positive expression $(+++)$ in the P4 group. HER2 immunostaining, hematoxylin counterstain.

P7 groups, equivocal HER2 expression was observed. It was thought that secondary metabolic compounds in CLEE may inhibit tumor cell development. This was proven by the finding that, when CLEE was stopped, normal cells began to proliferate again into tumor cells.

Caspase-3 expression showed brown-stained cell cytoplasm, which indicated the presence of apoptotic cells (Figure-3). Caspase-3 expression could be found in the tumor control group and treatment groups given MTX and CLEE at dosages of 300 and $400 \mathrm{mg} / \mathrm{kg}$ BW. This marker was used to evaluate the response to drug and extract treatments. In the control P1 group, apoptotic cells were detected in skin epidermis, hair follicles, and sebaceous glands in the mammary gland skin $(+)$. Caspase-3 overexpression was moderate $(++)$ in groups P2, P5, P6, and P7. Meanwhile, there was overexpression $(+++)$ of caspase- 3 in groups $\mathrm{P} 3$ and $\mathrm{P} 4$. Overexpression was found in mammary gland duct epithelial cells, epithelial cells outside the duct, fibrous cells, and PMN cells.

MTX (P3) and CLEE at a $300 \mathrm{mg} / \mathrm{kg}$ BW dosage (P4) showed similarly high apoptotic activity in HER2-positive mammary tumor cells. A high number of apoptotic cells were obtained with CLEE at a dose of $300 \mathrm{mg} / \mathrm{kg} \mathrm{BW}$, showing its effectiveness against malignant tumor cells. Therefore, it can be used as an anti-mammary tumor candidate.

\section{Discussion}

In this study, DMBA injection showed that the majority of mammary tumors were HER2-positive. The American Society of Clinical Oncology and the College of American Pathologists recommend that patients with mammary tumor can be characterized as being in the early or advanced stage based on HER 2 status (negative, equivocal, or positive), using one or more



Figure-3: Expression of caspase-3 (arrow). (a) The hair follicles of the skin of Sprague-Dawley rats as negative control are low immunoreactivities for caspase-3 in the P1 group. (b) Mammary gland epithelial cells are overexpressed of caspase-3 in the P2 group. (c) Duct epithelial cells (d) Epithelial cells were outside the duct of the mammary gland in the P4 group. Caspase-3 immunostaining, hematoxylin counterstain.

HER2 tests. HER2 positivity in an IHC test is defined when more than $10 \%$ of adjacent tumor cells homogeneously express HER2 in the cell membrane [4]. The categories are defined as follows: unstained or weakly and incompletely stained surrounding cells $(0 /+)$, surrounding cell membrane weakly stained or moderately stained at $>10 \%$ or membrane strongly stained in $\leq 10 \%$ of tumor cells $(++)$, and cell membrane strongly stained in $>10 \%$ of cells $(+++)$ [28]. Overexpression of HER2 could be found in $15-20 \%$ of invasive ductal carcinoma mammary tumors with intense brown color on the cell membrane from weakly to moderately stained in $>10 \%$ of tumor cells [29].

The overexpression of HER 2 is a poor prognostic factor associated with inadequate differentiation, high cell proliferation, metastasis to lymph nodes, and often resistance to specific chemotherapy. HER2 overexpression is also associated with a higher risk of recurrence compared with that in HER2-negative mammary tumor [30]. The HER group plays an important role in the signaling pathway controlling cell growth and differentiation. HER2 overexpression is necessary for cancerous transformation and tumorigenesis [31]. HER2 activates the phosphatidylinositol-3 kinaseAKT-NF-kB pathway to stimulate the mitogenic cyclic D1/CdK4-Rb-E2F pathway. HER2 overexpression also stimulates the autonomous tumor cell suppressor DmP1-Arf-P53 pathway to suppress the oncogenic signal, which results in the appearance of tumor cells [8]. Activity of the HER2 constitutive homodimer occurs due to HER2 overexpression on the cell surface. This makes cell growth unregulated and leads to oncogenic transformation. HER2 overexpression also contributes to malignant tumor growth through the recruitment of other HER receptors, especially HER3. HER3 has been shown to cause an increase in phosphotyrosine in 
HER2-positive tumors [31,32]. In the study, CLEE at a dose of $300 \mathrm{mg} / \mathrm{kg} \mathrm{BW}$ given preventively showed the potency of CLEE to suppress tumor cell growth with HER2 level $(++)$,while CLEE given curatively still showed HER2 level $(+++)$. However, the potency of CLEE for a curative effect was showed in apoptosis with caspase-3 level $(+++)$, similar to that of MTX therapy.

Apoptotic cells can commonly be found in normal tissue, but at a low level. Caspase- 3 expression is commonly found in cells in the body. In normal skin, caspase-3 expression-positive cells can be found in epidermal cells, namely, hair follicle epithelial cells, and sebaceous gland epithelial cells [33]. The characteristics of Caspase-3, as shown by IHC showed homogeneous brown positivity in the cell cytoplasm [34]. This research showed that high caspase-3 overexpression was found in the MTX-administered group (P3) and curative group (P4), which was given CLEE at a dosage of $300 \mathrm{mg} / \mathrm{kg} \mathrm{BW}$. High caspase-3 overexpression indicated that the mammary gland tumor cells underwent apoptosis, shrinking the tumor. This is in accordance with previous research showing that the tumor size was smaller in an MTX-administered group (P3) and a curative group (P4) given CLEE at $300 \mathrm{mg} / \mathrm{kg}$ BW. Palpation of the mammary glands revealed tumor nodules with a firm consistency. Histopathological imaging revealed neoplastic cells, fibroblast cell proliferation, glandular duct proliferation, and glandular epithelial cell proliferation. The tumor size in group P2 was greater than that in groups P3, P4, P5, $\mathrm{P} 6$, and P7. Meanwhile, the smallest tumor size was seen in the $\mathrm{P} 3$ and $\mathrm{P} 4$ groups [22].

The obtained results indicated that secondary metabolites contained in CLEE, especially alkaloid, terpenoid, and flavonoid compounds, may act as anti-tumor drugs. This is in line with the previous findings that compounds could suppress cell growth through DNA damage and apoptosis. Apoptosis could be detected through caspase-3 protein was one of the effector caspases helped by initiator caspase, which is very important in the apoptotic pathway [35-37]. Curry leaves are rich in bioactive compounds such as alkaloids and flavonoids, which are proven to improve caspase-3 activity by increasing mammary tumor cell apoptosis in nude mice and human mammary cancer cells (MDA-MB-231) [38]. Alkaloid compounds (murrayazoline and o-methylmurrayamine) were shown to activate the caspase- 3 protein, which regulated the induction of apoptosis in colon cancer cells (DLD-1) [36]. Compounds in curry leaves have also been reported to selectively inhibit cell proliferation and induce cell apoptosis in lung cancer cells A549. These compounds can increase the regulation of caspase- $3,-7$, and -9 , and release cytochrome $\mathrm{c}$ into the cytosol. This supports the involvement of mitochondria in the apoptotic process caused by alkaloid compounds in A549 cells [39].

In this research, the injection of DMBA led to the formation of malignant tumors (cancer) in mammary glands of rats with a HER2-positive status. The P4 group with HER2 positivity given CLEE at $300 \mathrm{mg} / \mathrm{kg}$ BW showed high overexpression of caspase-3. This is thought to be due to the high activity of secondary metabolic compounds in CLEE, which can cause apoptosis in tumor cells. Meanwhile, the activity of these CLEE compounds in the P5, P6, and P7 groups with a HER2-equivocal status led to moderate overexpression of caspase-3. Curry leaf extract can reduce cell viability and proliferation of MCF-7 and MDM-MB-231 breast cancer cells, while having no effect on normal cells [21]. Curry leaf extract inhibits the formation of mammary tumor, reducing mitotic cells and cytotoxicity [20].

\section{Conclusion}

Subcutaneous DMBA injection into the mammary glands can rapidly induce the formation of a mammary tumor within 14-21 days. The majority of mammary tumors formed were HER2-positive. CLEE at a dose of $300 \mathrm{mg} / \mathrm{kg} \mathrm{BW}$ in both curative and preventive administration had anti-tumor potency, which could effectively cause caspase- 3 overexpression, associated with the apoptosis of tumor cells.

\section{Authors' Contributions}

SA and AS: Designed the study. SA: Carried out the preparation of the sample. SA, EH, and NB: Performed data collection, statistical analysis, data interpretation, and manuscript writing. SA, NB, and AS: Involved in the monitoring of research and manuscript editing. All authors have read and approved the final manuscript.

\section{Acknowledgments}

The authors are highly thankful to the rector, Syiah Kuala University, Banda Aceh and IPB University, Bogor. The study was funded by the Ministry of Research and Technology of Higher Education, Indonesia (Grant no. 61053/A2.1/KP/2016).

\section{Competing Interests}

The authors declare that they have no competing interests.

\section{Publisher's Note}

Veterinary World remains neutral with regard to jurisdictional claims in published institutional affiliation.

\section{References}

1. International Agency for Research on Cancer. (2019) The Global Cancer Observatory: Indonesia. World Health Organization, Geneva.

2. Vyberg, M., Nielsen, S., Roge, R., Sheppard, B., RangerMoore, J., Walk, E., Gartemann, J., Rohr, U.P. and Teichgraber, V. (2015) Immunohistochemical expression of HER2 in breast cancer: Socioeconomic impact of inaccurate tests. BMC Health Serv. Res., 15: 352.

3. Kabel, A.M. and Baali, F.H. (2015) Breast cancer: Insights into risk factors, pathogenesis, diagnosis and management. JCRT, 3(2): 28-33. 
4. Furrer, D., Paquet, C., Jacob, S. and Diorio, C. (2018) The Human Epidermal Growth Factor Receptor 2 (HER2) as a Prognostic and Predictive Biomarker: Molecular Insights into HER2 Activation and Diagnostic Implications. Cancer Prognosis, Tamil Nadu. p11-31.

5. Kimberly, H.A., Hammond, M.E.H., Dowsett, M., McKernin, S.E., Carey, L.A., Fitzgibbons, P.L., Hayes, D.F., Lakhani, S.R., MacGregor, M.C., Perlmutter, J., Perou, C.M., Regan, M.M., Rimm, D.L., Syimmans, W.F., Torlakovic, E.E., Valella, L., Viale, G., Weisberg. T.F., McShane, L.M. and Wolff, A.C. (2020) Estrogen and progesterone receptor testing in breast cancer: ASCO/CAP guideline update. J. Clin. Oncol., 38(12): 1346-1366.

6. Duffy, M.J., Harbeck, N., Nap, M., Molina, R., Nicolini, A., Senkus, E. and Cardoso, F. (2017) Clinical use of biomarkers in breast cancer: Updated guidelines from the European group on tumor markers (EGTM). EJC., 75: 284-298.

7. Du, Z. and Lovly, C.M. (2018) Mechanisms of receptor tyrosine kinase activation in cancer. Mol. Cancer., 17(1): 58.

8. Fry, E.A., Taneja, P. and Inoue, K. (2017) Oncogenic and tumor-suppressive mouse models for breast cancer engaging HER2/neu. Int. J. Cancer, 140(3): 495-503.

9. Halle, M.K., Tangen, I.L., Berg, H.F., Hoivik, E.A., Mauland, K.K., Kusonmano, K., Berg, A., Hurtado, A., Kalland, K.H., Øyan, A.M., Stefansson, I., Vintermyr, O.K., Werner, H.M., Haldorsen, I.S., Trovik, J., Salvesen, H.B. and Krakstad, C. (2018) HER2 expression patterns in paired primary and metastatic endometrial cancer lesions. $B r . J$. Cancer., 118(3): 378-387.

10. Fabiano, V., Mando, P., Rizzo, M., Ponce, C., Colo, F., Loza, M., Loza, J., Amat, M., Mysler, D., Constanzo, M.V., Nervo, A., Nadal, J., Perazzo, F. and Chacon, R. (2020) Breast cancer in young women presents with more aggressive pathologic characteristics: Retrospective analysis from an argentine national database. JCO Global Oncol., 6: 639-646.

11. Yang, X., Zhong, D.N., Qin, H., Wu, P.R, Wei, K.L., Chen, G., He, R.Q. and Zhong, J.C. (2018) Caspase-3 over-expression is associated with poor overall survival and clinicopathological parameters in breast cancer: A meta-analysis of 3091 cases. Oncotarget, 9(9): 8629-8641.

12. Fatmawati, D., Suparmi., Yusuf, I. and Isradji, I. (2018) Anticancer selectivity of Sirsak (Annona muricata) leaf extract on breast cancer cell lines. Biosite, 4(2): 41-80.

13. Pfeffer, C.M. and Singh, A.T.K. (2018) Apoptosis: A target for anti-cancer therapy. Int. J. Mol. Sci., 19(2): 448.

14. Sivakumaran, N., Samarakoon, S.R., Adhikari, A., Ediriweera, M.K., Tennekoon, K.H., Malavige, N., Thabrew, I. and Shrestha, R.L. (2018) Cytotoxic and apoptotic effects of Govaniadine isolated from Corydalis govaniana Wall. Roots on human breast cancer (MCF-7) cells. Biomed. Res. Int., 2018: 1-11.

15. Seca, A.M.L. and Pinto, D.C.G. (2018) Review: Plant secondary metabolites as anti-cancer agents: Successes in clinical trials and therapeutic application. Int. J. Mol. Sci., 19(1): 263.

16. Utaipan, T., Athipornchai, A., Suksamran, A., Jirachotikoon, C., Yuan, X., Lertcanawanichakul, M. and Chunglok, W. (2016) Carbazole alkaloids from Murraya koenigii trigger apoptosis and autophagic flux inhibition in human oral squamous cell carcinoma cells. J. Nat. Med., 71(1): 158-169.

17. Pérez-Soto, E., Estanislao-Gómez, C.C., PérezIshiwara, D.G., Ramirez-Celis, C. and Gómez-García, M.C. (2019) Cytotoxic effect and mechanisms from some plant-derived compounds in breast cancer. In: Cytotoxicitydefinition, Identification, and Cytotoxic Compounds. IntechOpen, London, United Kingdom.

18. Amna, U., Halimatussakdiah., Wahyuningsih, P., Saidi, N. and Nasution, R. (2019) Evaluation of cytotoxic activity from Temurui (Murraya koenigii [Linn.] Spreng) leaf extracts against Hela cell line using MTT assay. J. Adv.
Pharm. Technol. Res., 10(2): 51-55.

19. Kammath, A.J., Nair, B., Sreelekshmi, P. and Nath, L.R. (2020) Curry versus cancer: Potential of some selected culinary spices against cancer with in vitro, in vivo, and human trials evidences. J. Food Biochem., 45(3): e13285.

20. Yeap, S.K., Abu, N., Mohamad, N.E., Beh, B.K., Ho, W.Y., Ebrahim, S., Yusof, H.M., Ky, H., Tan, S.W. and Alitheen, N.B. (2015) Chemopreventive and immunomodulatory effects of Murraya koenigii aqueous extract on 4T1 breast cancer cell-challenged mice. BMC Complement. Altern. Med., 15(306): 1-10.

21. Noolu, B., Gogulothu, R., Bhat, M., Qadri, S.S.Y., Reddy, V.S., Reddy, G.B. and Ismail, A. (2016) In vivo inhibition of proteasome activity and tumour growth by Murraya koenigii leaf extract in breast cancer xenografts and by its active flavonoids in breast cancer cells. Anticancer Agents Med. Chem., 16(12): 1605-1614.

22. Aisyah, S., Handharyani, E., Bermawie, N. and Setiyono, A. (2020) Potency of Murraya koenigii leaves as anti-cancer mammary in 7,12 dimethylbenz $(\alpha)$ anthracene (DMBA) induced-Sprague dawley rats. E3S Web Conf., 151: 1-5.

23. Tan, S.P., Ali. A.M., Nafiah, M.A., Awang, K. and Ahmad, K. (2015) Isolation and cytotoxic investigation of new carbazole alkaloids from Murraya koenigii (Linn.) Spreng. Tetrahedron, 71(23): 3946-3953.

24. Ismail, A., Noolu, B., Gogulothu, R., Perugu, S., Rajanna, A. and Babu, S.K. (2016) Cytotoxicity and proteasome inhibition by alkaloid extract from Murraya koenigii leaves in breast cancer cells-molecular docking studies. J. Med. Food, 19(12): 1155-1165.

25. Iman, V., Mohan, S., Abdelwahab, S.I., Karimian, H., Nordin, N., Fadaeinasab, M., Noodin, M.I. and Noor, S.M. (2017) Anticancer and anti-inflammatory activities of Girinimbine isolated from Murraya koenigii. Drug Des. Devel. Ther., 11: 103-121.

26. Patterson, J. and Verghese, M. (2015) Anticancer and toxic effects of curry leaf (Murraya koenigii) extracts. $J$. Pharmacol. Toxicol., 10(2): 49-59.

27. Wolff, A.C., Hammond, E.H., Hicks, D.G., Dowsett, M., McShane, L.M., Allison, K.H., Allred, D.C., Bartlett, J.M., Bilous, M., Fitzgibbons, P., Hanna, W., Jenkins, R.B., Mangun, P.B., Paik, S., Perez, E.A., Press, M.F., Spears, P.A., Vance, G.H., Viale, G. and Hayes, D.F. (2013) Recommendations for human epidermal growth factor receptor 2 testing in breast cancer: American society of clinical oncology/college of American pathologists clinical practice guideline update. J. Clin. Oncol., 31(31): 3997-4013.

28. Rakha, E.A., Pinder, S.E., Bartlett, J.M.S., Ibrahim, M., Starczynski, J., Carder, P.J., Provenzano, E., Hanby, A., Hales, S., Lee, A.H.S. and Ellis, I.O. (2015) Updated UK recommendations for HER2 assessment in breast cancer. $J$. Clin. Pathol., 68(2): 93-99.

29. Hsu, J.L. and Hung, M.C. (2016) The role of HER2, EGFR, and other receptor tyrosine kinases in breast cancer. Cancer Metastasis Rev., 35(4): 575-588.

30. Aman, N.A., Doukoure, B., Koffi, K.D., Koui, B.S., Traore, Z.C., Kouyate, M. and Effi, A.B. (2019) HER2 overexpression and correlation with other significant clinicopathologic parameters in Ivorian breast cancer women. BMC Clin. Pathol., 19(1): 4.

31. Ruiz-Saenz, A., Dreyer, C., Campbell, M.R, Steri, V., Gulizia, N. and Moasser, M.M. (2018) HER2 amplification in tumors activates P13K/Akt signaling independent of HER3. Cancer Res., 78(13): 3645-3658.

32. Gandullo-Sánchez, L., Capone, E., Ocaña, A., Lacobelli, S., Sala, G. and Pandiella A. (2020) HER3 targeting with an antibody-drug conjugate bypasses resistance to anti-HER2 therapies. EMBO Mol. Med., 12(5): e11498.

33. Bebars, S.M.M., Al-Sharaky, D.R., Gaber, M.A. and Afify, D.R. (2017) Immunohistochemical expression of caspase-3 in psoriasis. J. Clin. Diagn. Res., 11(17): 
EC01-EC05.

34. Huang, J.S., Yang, C.M., Wang, J.S., Liou, H.H., Hsieh, I.C., Li, G.C., Huang, S.J., Shu, C.W., Fu, T.Y., Lin, Y.C., Ger, L.P. and Liu, P.F. (2017) Caspase-3 expression in tumorigenesis and prognosis of buccal mucosa squamous cell carcinoma. Oncotarget., 8(48): 84237-84247.

35. Abotaleb, M., Samuel, S.M., Varghese, E., Varghese, S., Kubatka, P., Liskova, A. and Büsselberg, D. (2018) Flavonoids in cancer and apoptosis. Cancers., 11(1): 28.

36. Arun, A., Patel, O.P.S., Saini, D., Yadav, P.P. and Konwar, R. (2017) Anti-colon cancer activity of Murraya koenigii leaves is due to constituent murrayazoline and o-methylmurrayamine an induced mTOR/AKT downregulation and mitochondrial apoptosis. Biomed Pharmacother., 93: 510-521.

37. Shin, S.A., Moon, S.Y., Kim, W.Y., Paek, S.M., Park, H.H. and Lee, C.S. (2018) Structure-Based Classification and Anti-Cancer Effects of Plant Metabolites. Int. J. Mol. Sci., 19(9): 2651.

38. Ismail, A., and Noolu, B. (2015) Murraya koenigii leaves: A potent anti-cancer agent against breast cancer. J. Cancer Sci. Ther., 7: 10 .

39. Habli, Z., Toumieh, G., Fatfat, M., Rahal, O.N. and Muhtasib, H.G. (2017) Emerging cytotoxic alkaloids in the battle against cancer: Overview of molecular mechanisms. Molecules., 22(2): 250.

$* * * * * * * *$ 